\title{
Bibliometric Assessment Based on Web of Science Database: Educational Research Articles on Botanic Gardens, National Parks, and Natural Monuments
}

\author{
Aykut Emre Bozdoğan \\ Tokat Gaziosmanpaşa University, Education Faculty, Department of Maths and Science \\ Education, Tokat, Turkey, \\ ORCID: 0000-0002-5781-9960
}

\author{
Abdulkerim Demir * \\ Tokat Gaziosmanpaşa University, Education Faculty, Department of Turkish and Social \\ Sciences Education, Tokat, Turkey, \\ ORCID: 0000-0001-7968-9557
}

Dilek Şahinpınar

A ̆̆rı İbrahim Çeçen University, Department of Doğubayazıt Ahmed-i Hani Vocational

School, Child Care and Youth Services, A $\breve{g r l}$, Turkey,

ORCID: 0000-0001-9454-5308

\begin{tabular}{|c|c|}
\hline Article history & in this study to reve \\
\hline $\begin{array}{l}\text { Received: } \\
03.02 .2021\end{array}$ & $\begin{array}{l}\text { making a bibliometric evaluation of the educational research articles } \\
\text { published on botanic gardens, national parks, and natural monuments in }\end{array}$ \\
\hline $\begin{array}{l}\text { Received in revised form: } \\
29.06 .2021\end{array}$ & $\begin{array}{l}\text { the Web of Science (WoS) database. Within the scope of quantitative } \\
\text { methodology, the bibliometrics was applied in the study. The data were } \\
\text { taken from the WoS database generated by Clarivate Analytics. The study }\end{array}$ \\
\hline $\begin{array}{l}\text { Accepted: } \\
02.07 .2021\end{array}$ & $\begin{array}{l}\text { data covered the years between } 1975 \text { and } 2020 \text {. Bibliometric analysis } \\
\text { techniques were used in the analysis of the data. } 44,138 \text { records related to }\end{array}$ \\
\hline Key words: & the study subject were obtained in the WoS database, and 98 of them \\
\hline $\begin{array}{l}\text { Botanic gardens, } \\
\text { National park, } \\
\text { Natural monument, } \\
\text { Bibliometrics, } \\
\text { Web of Science }\end{array}$ & $\begin{array}{l}\text { were determined in the category of educational research. Analyses were } \\
\text { conducted on } 58 \text { articles in the category of educational research. As a } \\
\text { result of the analyses, it was observed that half of the articles were } \\
\text { published in the last } 5 \text { years. It was also concluded that the publication } \\
\text { language of the articles was predominantly English and that the } \\
\text { researchers working in the United States provided the highest } \\
\text { contribution to the related literature by producing } 20 \text { articles. In addition, } \\
\text { it was determined that the most effective journals related to the study } \\
\text { subject were "Environmental Education Research" and "Journal of } \\
\text { Environmental Education". A total of } 180 \text { different keywords were } \\
\text { included in the analyzed articles, and the most used ones were } \\
\text { "environmental education" and "botanic garden". It was also concluded } \\
\text { that } 1885 \text { different publications, } 1596 \text { authors, and } 1309 \text { sources were }\end{array}$ \\
\hline
\end{tabular}

\footnotetext{
*Correspondency: abdulkerim.demir@gop.edu.tr
} 
cited in the articles examined within this research. The articles in the WoS database were examined in this study, and it is important to carry out similar studies in different publication types and databases in terms of revealing the trend in this subject.

\section{Introduction}

At present, upon the schools' no longer being a learning environment on their own, educational activities have become possible to be carried out in many out-of-school environments, and this situation has brought out-of-school education to a more important position in educational aspect (Bozdoğan, 2008). Out-of-school education can generally be expressed as education provided in the school garden, around, or outside the school. The important features of out-of-school education are listed as that it covers people and places outside the school, that it is carried out in a planned and programmed way according to the achievements in the curriculum, that it is based on the individual experiences of the students, and that there is no hierarchical relationship between the student and the teacher (Şimşek \& Kaymakc1, 2015).

Educational activities that are implemented in out-of-school learning environments provide students the opportunity to gain experiences with the related knowledge directly. Studies have indicated that this situation increases interest of students in the lesson, helps them discover their own interests and abilities, contributes to their permanent learning by experiencing and having fun (Bostan Sarığlan \& Küçüközer, 2017; Bozdoğan, 2008; Bozdoğan \& Ustaoğlu, 2016; Ertaş, Şen \& Parmasızoğlu, 2011; Gökkaya \& Yeşilbursa, 2009; Kınasakal, Demir \& Kaymakc1, 2019; Şahin \& Sağlamer Yazgan, 2013).

There are many out-of-school learning environments that enable students embody knowledge and then learn by carrying the education given in schools out of the classroom. Botanic gardens, national parks, and natural monuments, which are the subject of the study, are also included in out-of-school learning environments in addition to such environments as museums, science and art centers, libraries, factories, government institutions, nongovernmental organizations, historical sites, zoos, planetariums, aquariums, and art galleries (Gerber, Cavallo, \& Marek, 2001; Hannu, 1993; Howe \& Disinger, 1988; Özgen, 2011; Şimşek \& Kaymakc1, 2015).

A botanic garden is defined as a living plant museum in which the trees, shrubs and other woody and herbaceous plants, each of which are accurately and carefully labeled, are exhibited and brought together for scientific research (Yaltırık, 1969). In botanic gardens, plants that are in danger of extinction/endangered in the wild are cultivated, and seeds are also protected and improved. Besides, these places associate plants with human well-being and protect local knowledge to promote the sustainable use of plant resources for the benefit of all. Many scientific activities related to plant taxonomy and genetics, research and development of plant characteristics and characteristics of changing environments are carried out in botanic gardens. In addition to this, botanic gardens have such recreational qualities as serving the community and ensuring that their visitors have fun in the open and green area system of the city where they are located. Botanic gardens provide visitors with the opportunity to observe the seasonal changes of plants and to meet them with natural. These places introduce many different aspects of plant species in different parts of the world and in their own geographies/habitats to visitors from all age groups. Organizing courses on the usage areas of plants and having information boards, botanic gardens directly or indirectly educate their visitors and contribute to the formation of environmental awareness and 
conservation awareness (BGCI, 2021; Coşkun Hepcan \& Özkan, 2005; Demircan \& Y1lmaz, 2004; Karaşah \& Var, 2016). It is also observed in the literature that there are studies on the use of botanic gardens for education and training activities. The effects of out-of-school educational activities in botanic gardens on the academic success of students (Günay, 2019; Şahin \& Sağlamer Yazgan, 2013; Türkmen, Topkaç \& Atasayar Yamık 2016), educational functions of botanic gardens (İri Karadeniz, 2017; Karsl1, Karamustafaoğlu, 2019; January \& Öztürk Kurtaslan, 2015; Özay Köse \& Gül, 2019; Şat, 2006), and opinions of teachers (Bayındır, 2010; Çiçek \& Saraç, 2017) and pre-service teachers (Atmaca, 2012; Mertoğlu, 2019) about botanic gardens were examined in the studies in the related literature.

Another out-of-school learning environment, which is the research subject of the study, is national parks. The International Union for Conservation of Nature (IUCN) defines the national parks as large natural or near-natural areas that are reserved to protect large-scale ecosystem processes, that contain the living species and ecosystem characteristics of the region, and provide religious, scientific, educational, entertaining and touristic opportunities that are compatible with both the environment and culture (Dudley, 2008). The initial purpose of these parks is to protect the natural and cultural heritage of an area and to provide representative examples reflecting the diversity of ecosystems (Papp \& Thompson, 2015). National parks are very attractive in terms of environmental education as well as nature protection and are also areas where in-service training is provided for many sectors. Depending on their resource values, these areas offer many training opportunities on various subjects such as ecological agriculture, animal husbandry, ecotourism, tourism guidance, and bird watching, which will contribute to rural development (Kurdoğlu, Kurdoğlu \& Şen, 2005). When the literature is examined, it is seen that there are studies on the educational dimension of national parks. The educational dimension of national parks in the education of nature (Kalender, 2010; Oğurlu, 2016; Vekli, 2019) and environment (Köksal, 2005; Öz, Bakım \& Yıldırım, 2013), attitudes of students (Deniş \& Genç, 2010; Deniş, Genç \& Demirkaya, 2008) and teachers (Karakaş \& Genç, 2020) towards national parks, the usability of national parks in education (Gülüm \& Okuyucu, 2016; Zaman \& Coşkun, 2012), and the importance of national parks in gaining touristic values (Kırboğa, 2020) and increasing ecological awareness (Kocalar, 2016) were examined in the studies available in the related literature.

Another and last form of out-of-school learning environment examined within the scope of the study is natural monuments. Natural monuments, formed in special geological conditions, are present representatives of natural history and geological phenomena. For a formation to be a natural monument, it must be formed without human touch, occur in the formation process of the Earth, and undergo changes through the influence of natural events. Caves, waterfalls, travertines, canyons, mountains, and alike which are spontaneously formed under natural conditions, have the features of natural monuments. These monuments, which have rare and extraordinary structures, provide information about the past by carrying along the reflection of natural events in all periods of natural history. It is extremely important to protect these monuments, which are almost impossible to replicate and repair (Laçin Şimşek, 2020; Özdemir, 1990). Natural monuments with rare features serve for many scientific, cultural, recreational, and touristic purposes at national and international level (Koçman, 2004).

When the studies on botanic gardens, national parks, and natural monuments included within the scope of this study are evaluated in general, it is observed that such subjects as the opinions of students and teachers on out-of-school learning environments, the place and importance of these environments in education are frequently examined in these studies. However, revealing the dynamics, changes, research innovations and trends related to the out- 
of-school learning environments that are the subject of the study is important in terms of providing the objectification of the examined situation. Such studies are called bibliometric analysis in the literature. When the literature is examined, it is seen that there are bibliometric studies on many different subjects and fields such as education (Aksoy, Bozdoğan \& Sönmez ,2021; Bozdoğan, 2020a; Bozdoğan, 2020b; Doğru, Güzeller \& Çelik, 2019; Karagöz \& Koç Ardıç, 2019; Karagöz \& Şeref, 2019a; Karagöz \& Şeref, 2020; Sönmez, 2020; Swain, 2014; Şeref \& Karagöz, 2019a ; Varışoğlu, Şahin, \& Göktaş, 2013), health (Becerikli, 2013; Koley \& Sen, 2016; Tsay \& Yang, 2005), economy (Beşel \& Yarcimcioğlu, 2017; Çetinkaya Bozkurt \& Çetin, 2016), gastronomy (Ayaz \& Turkmen , 2018), culture and art (İnceoğlu, 2014; Wang \& Ho, 2017; Yalçın \& Yayla, 2016), engineering (Parvathamma \& Banu, 2013), biology (Liu, Zhang \& Hong, 2011), literature (Karagöz \& Şeref, 2019b; Şeref \& Karagöz, 2019b), and tourism (Bozok, Kılıç \& Özdemir, 2017).

It is purposed in this study to reveal the trend in this field by making a bibliometric evaluation of the articles published on botanic gardens, national parks, and natural monuments in the Web of Science (WoS) database, which is widely used by researchers at the international level.

In this context, answers were sought for the following research questions:

(1) How is the distribution of publications scanned with the keywords of "botanic gardens, national parks, and natural monuments" into WoS categories?

(2) What are the types of publications on botanic gardens, national parks, and natural monuments in the Education/Educational Research category?

(3) How is the numerical distribution of articles published on botanic gardens, national parks, and natural monuments in the Education/Educational Research category by years?

(4) How is the citation distribution of articles published on botanic gardens, national parks, and natural monuments in the Education/Educational Research category by years?

(5) What are the most cited articles on botanic gardens, national parks, and natural monuments in the Education/Educational Research category?

(6) Which countries are active within the scope of articles published on botanic gardens, national parks, and natural monuments in the category of Education/Educational Research?

(7) What are the active publication languages within the scope of articles on botanic gardens, national parks, and natural monuments in the Education/Educational Research category?

(8) Which journals are active within the scope of articles published on botanic gardens, national parks, and natural monuments in the category of Education/Educational Research?

(9) Which institutions are active within the scope of articles published on botanic gardens, national parks, and natural monuments in the category of Education/Educational Research?

(10) What is the keyword network of articles published on botanic gardens, national parks, and natural monuments in the category of Education/Educational Research?

(11) Which are the most cited publications within the scope of articles published on botanic gardens, national parks, and natural monuments in the Education/Educational Research category? 
(12) Who are the most cited authors within the scope of articles published on botanic gardens, national parks, and natural monuments in the Education/Educational Research category?

(13) Which are the most cited sources from the journals publishing about botanic gardens, national parks, and natural monuments in the Education/Educational Research category?

\section{Method}

\section{Research Design}

In this study, bibliometrics was used to examine the performance of international educational articles in the field of botanical gardens, national parks and natural monuments. Bibliometrics uses quantitative analysis and statistics to describe the general characteristics of published works related to a particular subject or field (Pritchard, 1969). With bibliometric research, the most productive researchers and studies related to a subject or field can be determined ( $\mathrm{Al}, 2008)$. In this context, this method was used in the study to examine the articles published in the field of education on botanical gardens, national parks and natural monuments in terms of bibliometric parameters and to reveal the current situation.

\section{Data Collection Process}

The scope of the database is the essential component of a bibliometric study (Thompson, 2018). WoS, Scopus, and Google Scholar are among the most widely used databases in the world. The bibliometric data used within the scope of the study were taken from the WoS database generated by Clarivate Analytics. The WoS database is one of the leading scientific citation search and analytical information platforms with its collection of information across the world. This database provides researchers with a comprehensive and detailed data content from many disciplines and the opportunity to conduct in-depth analysis on the content ( $\mathrm{Li}$, Rollins, \& Yan, 2018). In this regard, the WoS database was preferred for this study.

The bibliometric analysis process was carried out as follows:

- An online search was conducted in the WoS database covering the years between 1975 and 2020.

- The keywords "botanic garden, national park, and natural monument" used in the search were scanned both in the article titles and in the content of the article.

- The scanned indexes were determined as SCI-Expended, SSCI, A\&HCI, CPCI-S, CPCI-SSH, BKCI-S, BKCI-SSH, and ESCI.

- 44,138 records related to keywords were accessed.

- 98 of the 44,138 records accessed are within the scope of Education/Educational Research, and the study was limited to the article with the highest number of records.

\section{Data Analysis}

Bibliometric analysis techniques were applied to analyze the articles examined within the scope of the study. In this type of analysis, the whole or a certain section of the literature is proceeded, and the change and development of the situation examined in scientific studies are clearly revealed. Unlike content analysis or document analysis, bibliometric analysis is very functional in terms of revealing the dynamics, changes, research innovations, and trends of a field. In this way, it makes the situation under examination objectify (İnceoğlu, 2014; 
Karagöz \& Şeref, 2019). The data obtained in the study were compared by the researchers, and after the differing data were reviewed, the final figures were obtained. Appropriate ones from these records were determined and presented in tables and figures.

VOSviewer (V 1.6.15) package program was utilized to generate the bibliometric network maps of the articles examined within the scope of the study and to visualize them. The publication, author, and source partner network maps are presented in figures through the keyword network map visualized thanks to the program. Finally, the map showing the distribution of the examined articles across the world was created through Datawrapper.

\section{Findings}

Within the scope of the study, an online search was conducted in the WoS database through the keywords "botanic garden, national park, and natural monument", and the articles in the WoS Education/Educational Research category were analyzed through the bibliometric analysis technique. The findings obtained as a result of the analyses are presented in this part of the study. Initially, the WoS categories of 44,138 studies obtained as a result of the scan were examined, and the first 10 categories are presented in Table 1.

Table 1. WoS categories of the publications scanned with the keywords "botanic gardens, national parks, and natural monuments" (Top 10 categories)

\begin{tabular}{ll}
\hline WoS Categories & Record Number \\
\hline 1. Ecology & 11.144 \\
2. Zoology & 6.814 \\
3. Ecological Sciences & 6.790 \\
4. Biodiversity Conservation & 4.612 \\
5. Botanical Sciences & 3.100 \\
6. Interdisciplinary Earth Sciences & 3.029 \\
7. Forestry & 2.760 \\
8. Physical Geography & 1.818 \\
9. Environmental Studies & 1.801 \\
10. Multidisciplinary Sciences & 1.489 \\
66. Education/Educational Research* & 98 \\
\hline
\end{tabular}

When Table 1 is examined, it is comprehended that the records with the most number are in the "Ecology" category with 11,144 studies. This is followed by studies in the categories of "Zoology" with 6,814 studies, "Ecological Sciences" with 6,790 studies, and "Biodiversity Conservation" with 4,612 studies. The category of "Education/Educational Research" ranks $66^{\text {th }}$ with 98 records.

The types of publications in the Education/Educational Research category are examined and presented in Figure 1. 


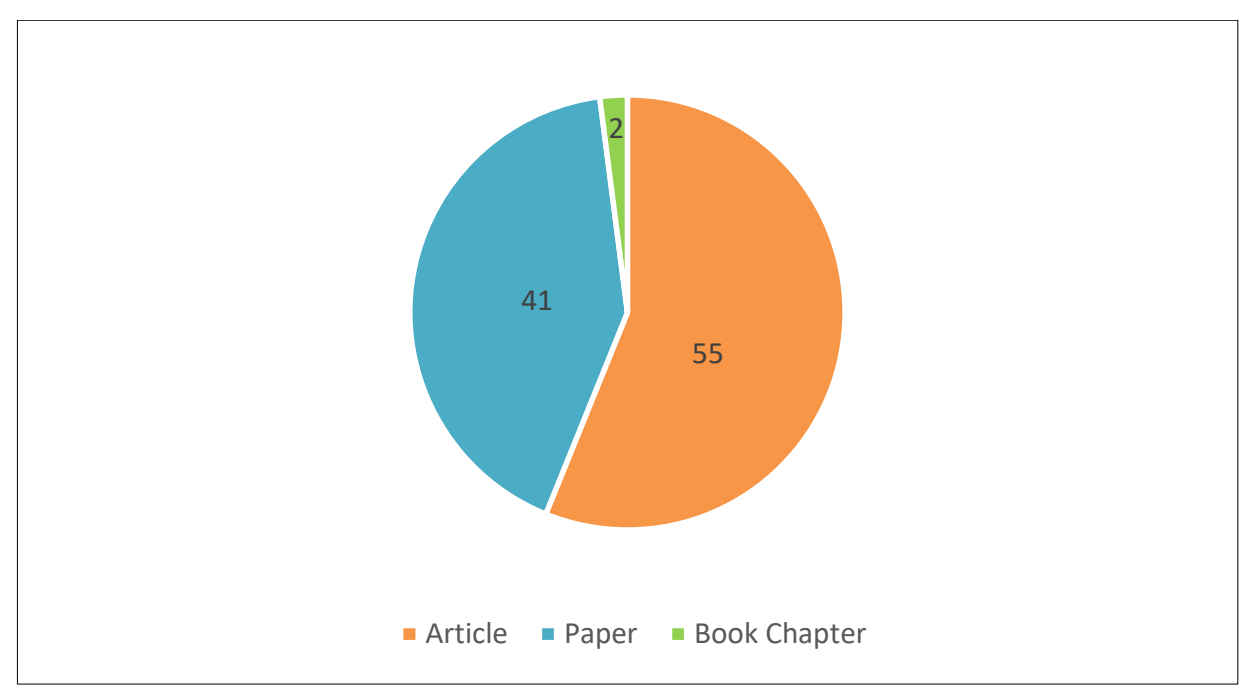

Figure 1. Types of publications within the scope of Education/Educational Research

When Figure 1 is examined, it is seen that the most publication type is articles with 55 studies. This is followed by paper publication with 41 studies and book chapter type with 2 studies.

The numerical distribution of 55 articles on botanic gardens, national parks, and natural monuments published in the Education/Educational Research category by years is examined and presented in Figure 2.

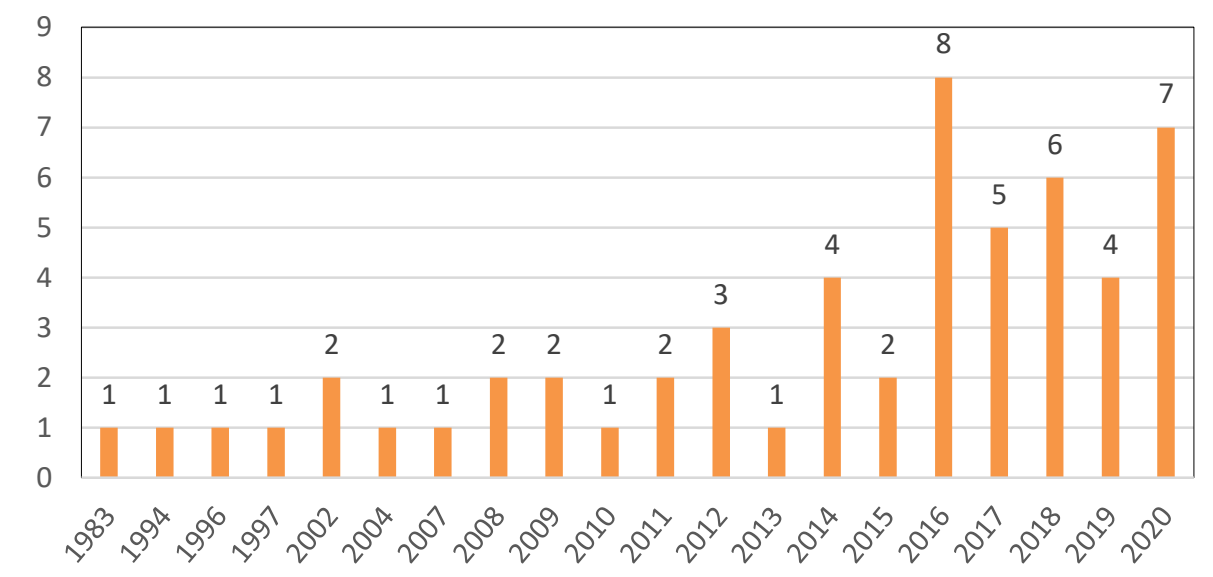

Figure 2. Numerical distribution of articles on botanic gardens, national parks, and natural monuments in the Education/Educational Research category by years $(\mathrm{N}=55)$

When the numerical distribution of the articles published on botanic gardens, national parks, and natural monuments in the Education/Educational Research category by years is examined, it is observed that the most articles were published in 2016 (8 articles), respectively followed by 2020 ( 7 articles) and 2018 ( 6 articles). It is also determined that 54.5\% of the articles (30 articles) were published in the last five years.

The citation distribution of the articles published on botanic gardens, national parks, and natural monuments in the Education/Educational Research category by years is examined and presented in Figure 3. 


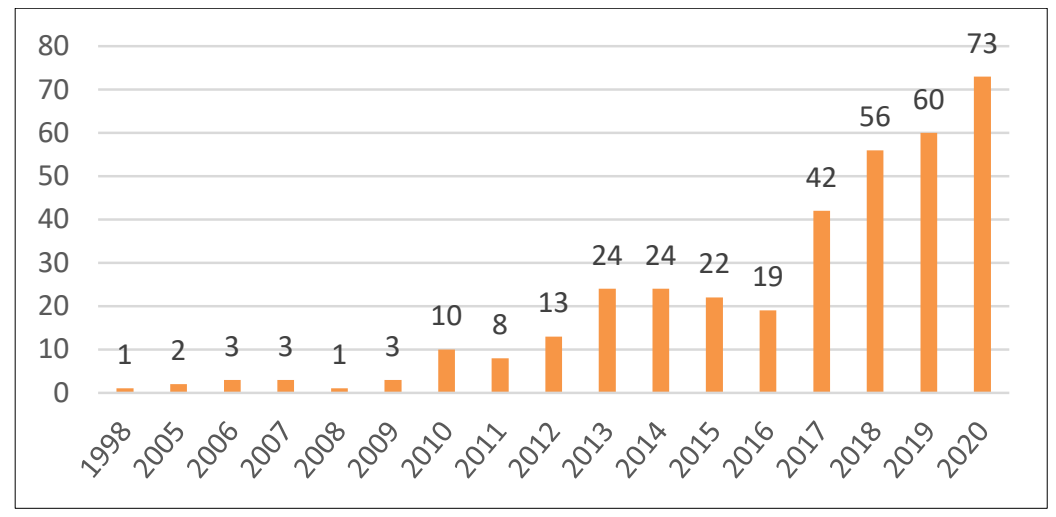

Figure 3. Citation distribution of articles on botanic gardens, national parks, and natural monuments in the Education/Educational Research category by years

It is seen that a total of 364 citations were made to articles published on botanic gardens, national parks, and natural monuments in the Education/Educational Research category. When the numerical distribution of the citations made to these articles by years is examined, it is observed that the most citations were made in 2020 (73 citations), respectively followed by 2019 (60 citations) and 2018 (56 citations).

Articles with 10 or more citations related to botanic gardens, national parks, and natural monuments in the Education/Educational Research category are reviewed and presented in Table 2.

Table 2. Articles with 10 or more citations on botanic gardens, national parks, and natural monuments in the Education/Educational Research category

\begin{tabular}{|c|c|c|c|c|c|}
\hline Article Title & Authors & Year & Journal Name & $\begin{array}{l}\text { Total } \\
\text { Citation } \\
\text { Number }\end{array}$ & $\begin{array}{l}\text { Citation } \\
\text { Number / } \\
\text { Year }\end{array}$ \\
\hline $\begin{array}{l}\text { What Difference Does It Make? } \\
\text { Assessing Outcomes from Participation } \\
\text { in a Residential Environmental } \\
\text { Education Program }\end{array}$ & $\begin{array}{l}\text { Stern, M.J. } \\
\text { Powell, R. B. } \\
\text { Ardoin, N. M. }\end{array}$ & 2008 & $\begin{array}{l}\text { The Journal of } \\
\text { Environmental } \\
\text { Education }\end{array}$ & 70 & 5 \\
\hline $\begin{array}{l}\text { Impact of a Student-Teacher-Scientist } \\
\text { Partnership on Students' and Teachers' } \\
\text { Content Knowledge, Attitudes Toward } \\
\text { Science, and Pedagogical Practices }\end{array}$ & $\begin{array}{l}\text { Houseal, A. K. } \\
\text { Abd-El-Khalick, } \\
\text { F. } \\
\text { Destefano, L. }\end{array}$ & 2014 & $\begin{array}{l}\text { Journal } \\
\text { Research } \\
\text { Science } \\
\text { Teaching }\end{array}$ & 39 & 4.88 \\
\hline $\begin{array}{l}\text { Park visitors' understandings, values and } \\
\text { beliefs related to their experience at } \\
\text { Midway Geyser Basin, Yellowstone } \\
\text { National Park, USA }\end{array}$ & $\begin{array}{l}\text { Brody, M. } \\
\text { Tomkiewicz, W. } \\
\text { Graves, J. }\end{array}$ & 2002 & $\begin{array}{l}\text { International } \\
\text { Journal of } \\
\text { Science } \\
\text { Education } \\
\text { International }\end{array}$ & 37 & 1.85 \\
\hline $\begin{array}{l}\text { Learning argumentation skills through } \\
\text { instruction in socio-scientific issues: The } \\
\text { effect of ability level }\end{array}$ & $\begin{array}{l}\text { Lin, S.S. } \\
\text { Mintzes, J. J. }\end{array}$ & 2010 & $\begin{array}{l}\text { International } \\
\text { Journal of } \\
\text { Science and } \\
\text { Mathematics } \\
\text { Education }\end{array}$ & 31 & 2.67 \\
\hline $\begin{array}{l}\text { Drawing attention to the 'green side of } \\
\text { life' }\end{array}$ & $\begin{array}{l}\text { Nyberg, E. } \\
\text { Sanders, D. }\end{array}$ & 2014 & $\begin{array}{l}\text { Journal of } \\
\text { Biological } \\
\text { Education }\end{array}$ & 24 & 3.13 \\
\hline $\begin{array}{l}\text { Environmental education in botanic } \\
\text { gardens: Exploring Brooklyn botanic } \\
\text { garden's project green reach }\end{array}$ & $\begin{array}{l}\text { Morgan, S. C. } \\
\text { Hamilton, S. L. } \\
\text { Bentley, M. L. }\end{array}$ & 2009 & $\begin{array}{l}\text { The Journal of } \\
\text { Environmental } \\
\text { Education }\end{array}$ & 17 & 1.31 \\
\hline
\end{tabular}


Young people's cognitive achievement as fostered by hands-on-centred environmental education

Communicating Science to Students: Investigating Professional Botanic Garden Educators' Talk During Guided School Visits

The effect of audio tours on learning and social interaction: An evaluation at Carlsbad Caverns National Park

\begin{tabular}{|c|c|c|c|c|c|}
\hline $\begin{array}{l}\text { Dieser, } \\
\text { Bogner, F. X. }\end{array}$ & 2016 & $\begin{array}{l}\text { Environm } \\
\text { Education } \\
\text { Research }\end{array}$ & & 10 & 1.67 \\
\hline $\begin{array}{l}\text { Zhai, J. } \\
\text { Dillon, J. }\end{array}$ & 2014 & $\begin{array}{l}\text { Journal } \\
\text { Research } \\
\text { Science } \\
\text { Teaching }\end{array}$ & $\begin{array}{l}\text { of } \\
\text { in }\end{array}$ & 10 & 1.25 \\
\hline $\begin{array}{l}\text { Novey, L. T. } \\
\text { Hall, T. E. }\end{array}$ & 2007 & $\begin{array}{l}\text { Science } \\
\text { Education }\end{array}$ & & 10 & 0.67 \\
\hline
\end{tabular}

When Table 2 is examined, it is seen that the most cited study in the Education/Educational Research category is "What Difference Does It Make? Assessing Outcomes from Participation in a Residential Environmental Education Program” by Stern, Powell and Ardoin, published in The Journal of Environmental Education. A total of 70 citations were made to the article published in 2008, with an annual average of 5 citations. This publication is followed by the article titled as "Impact of a Student-Teacher-Scientist Partnership on Students' and Teachers' Content Knowledge, Attitudes Toward Science, and Pedagogical Practices" by Houesal, Abd-El-Khalick and Destefano with a total of 39 citations and an average of 4.88 citations. It is also observed that the only article originating from Turkey is the article named "Experiential Results of Nature Camp Training" published in Education and Science in 2018 by Karakas, Kaya and Y1lmaz.

The countries that are active within the scope of the articles published on botanic gardens, national parks, and natural monuments in the category of Education/Educational Research is examined and presented in Figure 4.

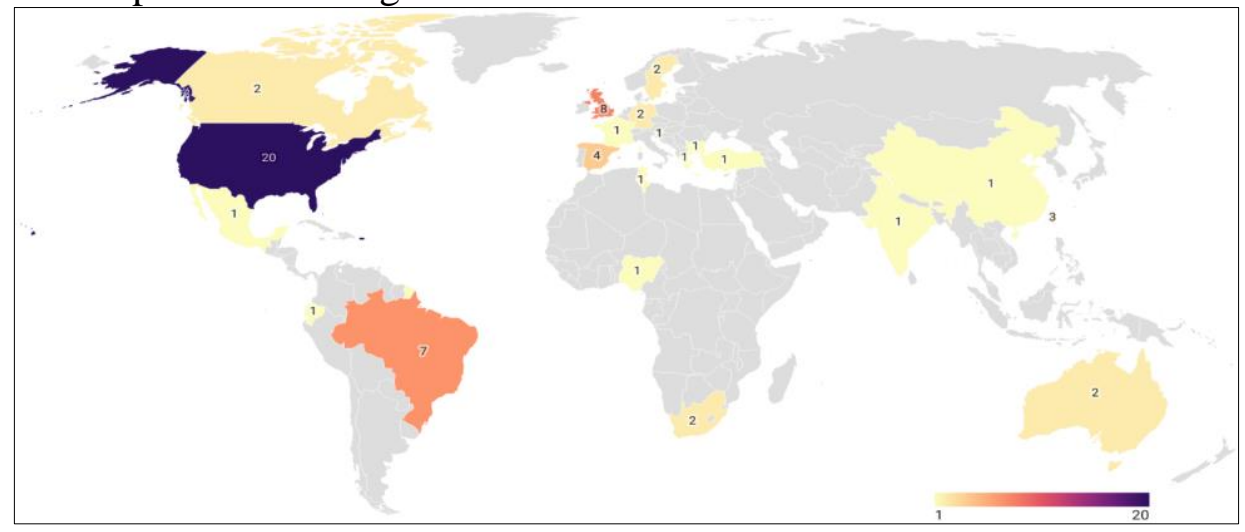

Figure 4. Countries active within the scope of articles published on botanic gardens, national parks, and natural monuments in the Education/Educational Research category $(\mathrm{N}=55)$

It is seen in the analyses that the researchers from 21 different countries have published articles that contribute to the field. In this context, when Figure 4 is examined, the United States of America (USA) is the most active country with 20 articles. This country is followed by the United Kingdom ( 8 articles), Brazil ( 7 articles), Spain (4 articles), and Taiwan (3 articles). One article from Turkey is also included in the list.

The active publication languages within the scope of articles on botanic gardens, national parks, and natural monuments in the Education/Educational Research category are examined and presented in Figure 5. 


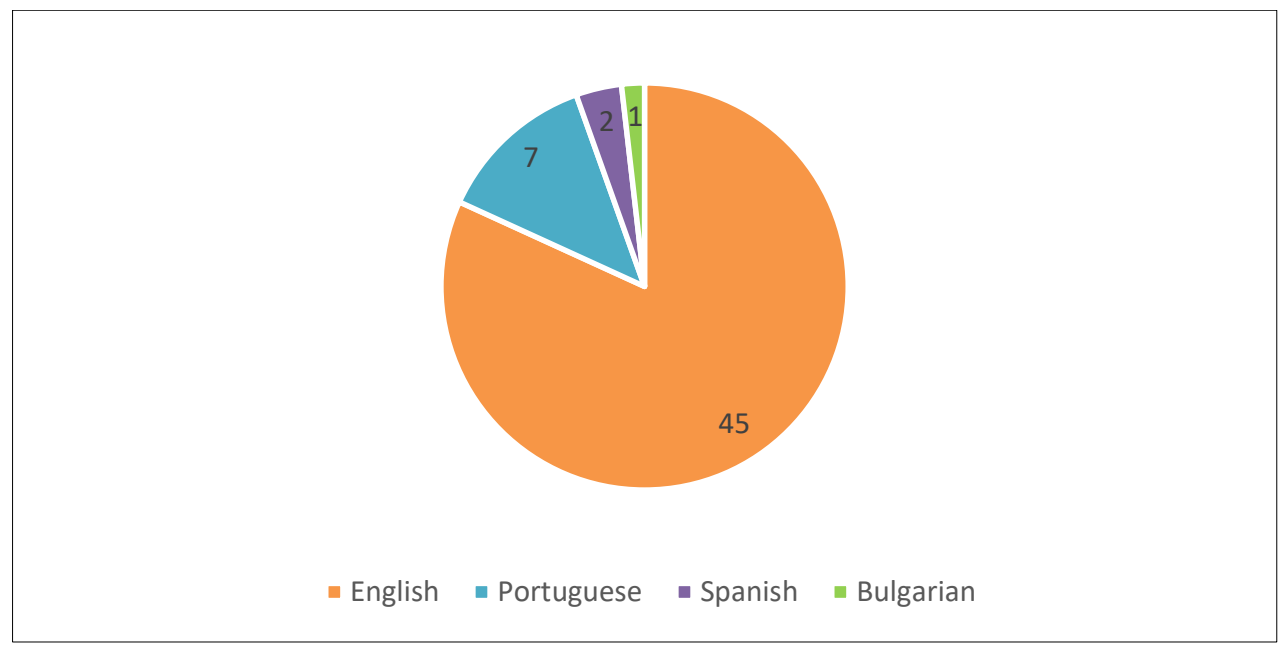

Figure 5. Publication languages active within the scope of articles on botanic gardens, national parks, and natural monuments in the category of Education/Educational Research (N $=55$ )

When Figure 5 is examined, it is comprehended that a total of 45 articles are published in English, 7 articles in Portuguese, 2 articles in Spanish, and 1 article in Bulgarian.

The journals that are active within the scope of the articles published on botanic gardens, national parks, and natural monuments in the Education/Educational Research category are examined, and the journals that have published two or more articles are presented in Table 3.

Table 3. Journals active within the scope of articles published on botanic gardens, national parks, and natural monuments in the Education/Educational Research category $(\mathrm{N}=55)$

\begin{tabular}{ll}
\hline Journals & Record Number \\
\hline Environmental Education Research & 6 \\
Journal of Environmental Education & 6 \\
Remea Revista Eletronica do Mestrado em Educacao Ambiental & 5 \\
Case Studies in the Environment & 4 \\
Journal of Biological Education & 4 \\
Geosaberes & 2 \\
Journal of Geography in Higher Education & 2 \\
Journal of Research in Science Teaching & 2 \\
Research in Science Education & 2 \\
\hline
\end{tabular}

It is concluded in the analysis that the articles were published in 32 different journals. In this context, when Table 3 is examined, it is seen that the most effective journals are Environmental Education Research (6 articles) and Journal of Environmental Education (6 articles). These are followed by Remea Revista Eletronica do Mestrado em Educacao Ambiental [REMEA (5 articles)], Case Studies in the Environment (4 articles), and Journal of Biological Education (4 articles).

The institutions that are active within the scope of the articles published on botanic gardens, national parks, and natural monuments in the Education/Educational Research category are examined, and the institutions that have published two or more articles are presented in Table 4. 
Table 4. Institutions active within the scope of articles published on botanic gardens, national parks, and natural monuments in the category of Education/Educational Research $(\mathrm{N}=55)$

\begin{tabular}{ll}
\hline Institutions & Record Number \\
\hline California State University Chico & 2 \\
Clemson University & 2 \\
King's College London & 2 \\
Stanford University & 2 \\
University of Wyoming & 2 \\
Virginia Tech University & 2 \\
\hline
\end{tabular}

Within the scope of articles published on botanic gardens, national parks, and natural monuments in the Education/Educational Research category, researchers from 83 different institutions contributed to the field. In this context, when Table 4 is examined, it is observed that the most effective institutions have at most 2 articles. These institutions are respectively California State University Chico, Clemson University, King's College London, Stanford University, University of Wyoming, and Virginia Tech University. Bilecik Seyh Edebali University and Sakarya University from Turkey are among the institutions that contribute to this field.

The keyword network of articles published on botanic gardens, national parks, and natural monuments in the Education/Educational Research category was examined. It is determined in the examination that a total of 180 different keywords were used in the articles. The scientific network map for the keywords is provided in Figure 6.

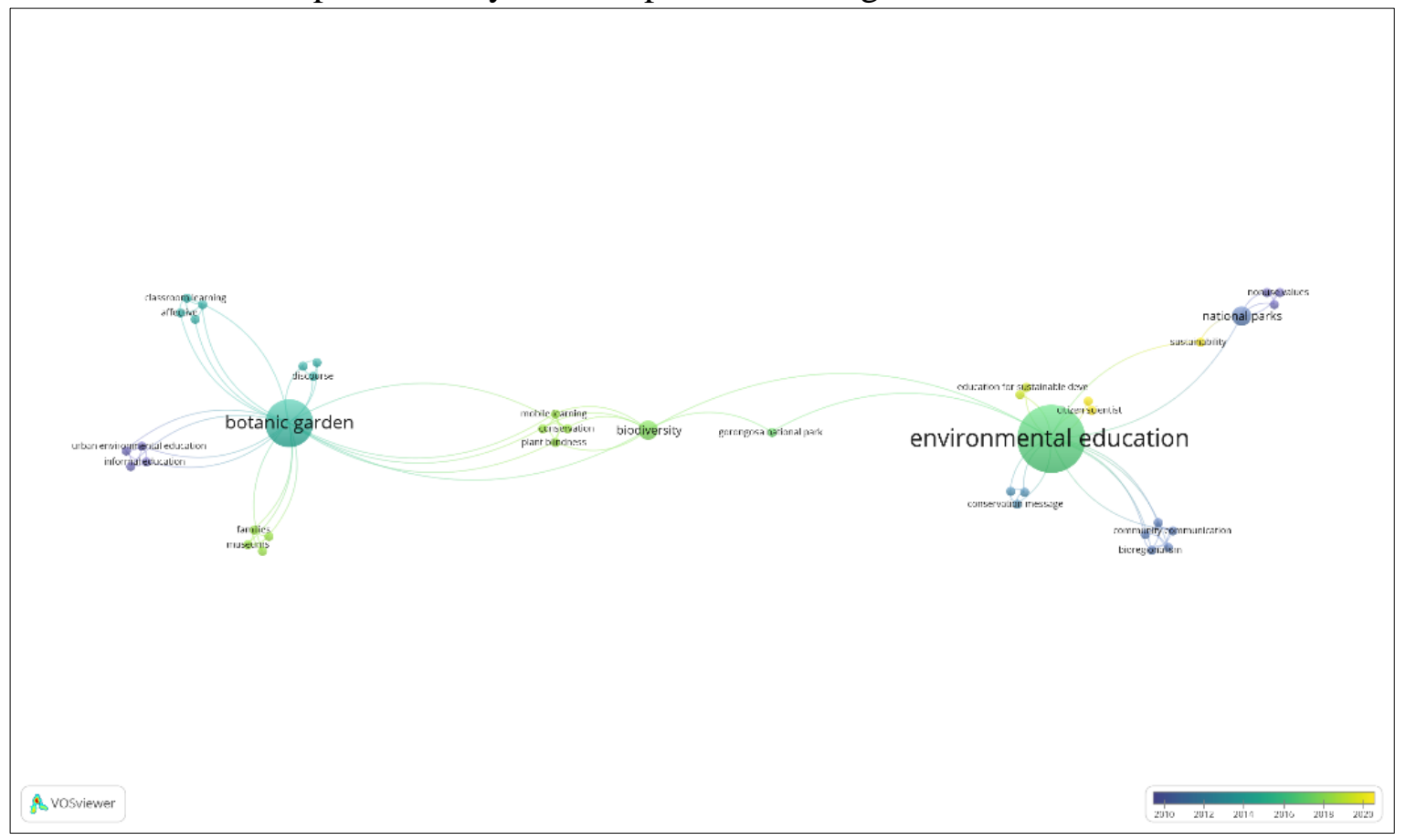

Figure 6. Keywords and current topic analysis

When Figure 6 is examined, it is understood that the most frequently used keywords in the articles are environmental education ( 7 times) and botanic garden (5 times). When the colorings of the years in which the keywords are used are examined, it is seen that such keywords as national parks, informal education, urban environmental education between 2010 and 2012; botanic garden, classroom learning between 2012 and 2014; environmental education between 2014 and 2016; biodiversity and mobile learning between 2016 and 2018 
were used in the articles. Also, it is determined that there has been a tendency towards such keywords as citizen scientist, education for sustainable development, and sustainability in recent years.

The publication co-citation network of the articles published on botanic gardens, national parks, and natural monuments in the category of Education/Educational Research was examined. It was determined in the examination that a total of 1885 different publications were cited. Of these, 48 publications with 2 or more citations were evaluated. The obtained results are shown in Figure 7.

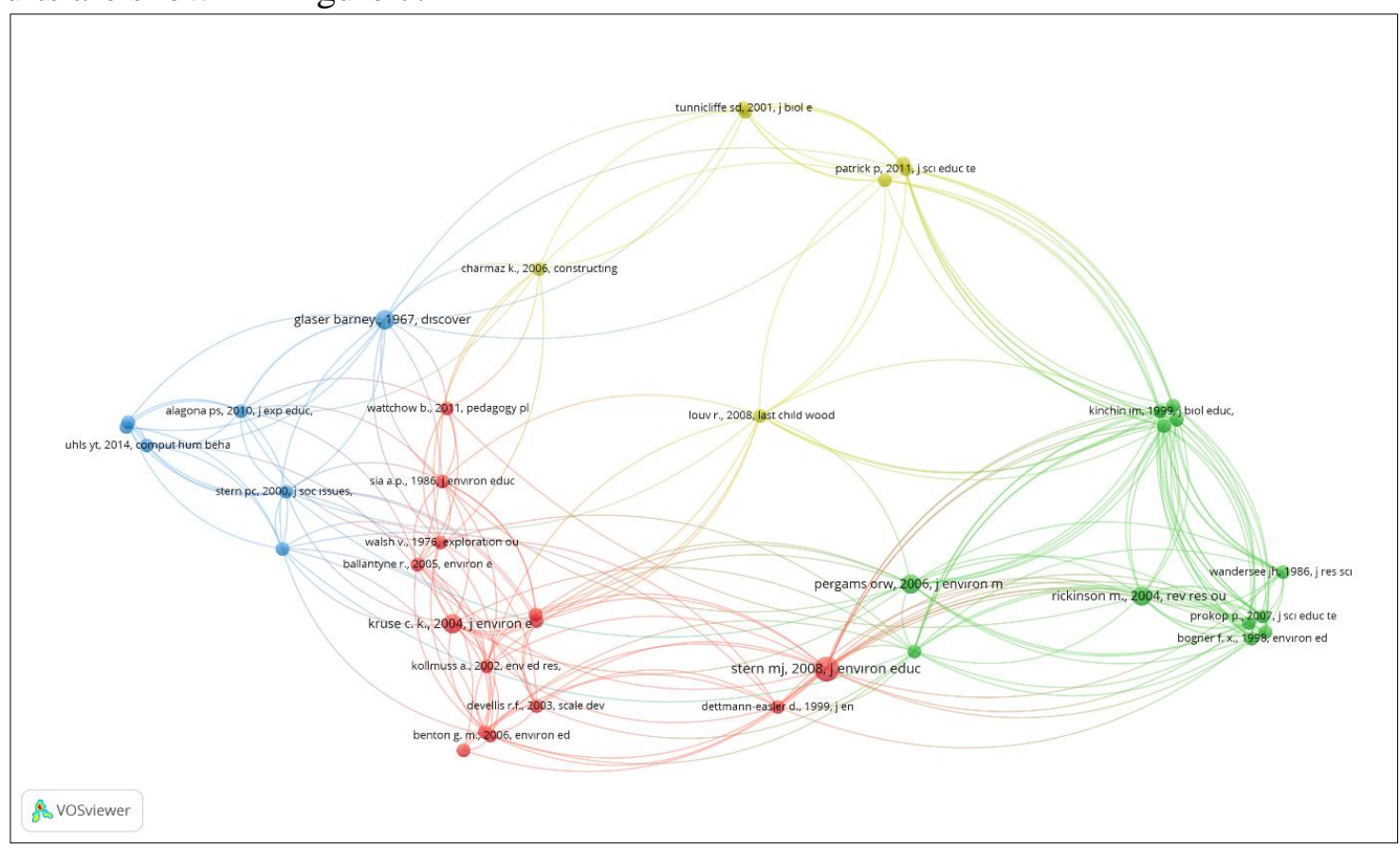

Figure 7. Publication co-citation network

When Figure 7 is examined, it is observed that the publications cited together in the articles published on botanic gardens, national parks, and natural monuments are grouped in 4 clusters. There are 14 publications in the red cluster, 12 in the green cluster, and seven each in the blue and yellow clusters.

The publication that stands out among the publications cited in the red cluster and has the highest total connection strength (TCS) is What Difference Does It Make? Assessing Outcomes from Participation in a Residential Environmental Education Program (TCS=20, Connection=20) by Marc J. Stern, Robert B. Powell and Nicole M. Ardoin. The article was published in the Journal of Environmental Education in 2008. Researchers examined the impact of the environmental education program on participants' awareness of their connection with nature, environmental management, and interest in learning and discovery.

The leading publication in the green cluster is the article titles as Is Love of Nature in the US Becoming Love of Electronic Media? 16-Yeardowntrend in National Park Visits Explained by Watching Movies, Playing Video Games, Internet Use, and Oil Prices (TCS=19, Connection=19) by Oliver R. W. Pergams and Patricia A. Zaradic. The article was published in the Journal of Environmental Management in 2006. The study examines the relationship between the decline in visits per capita to US national parks and the development of electronic entertainment media. 
The prominent publication in the blue cluster is the book titled as The Discovery of Grounded Theory: Strategies for Qualitative Research $(\mathrm{TCS}=16$, Connection=15) by Barney G. Glaser and Anselm L. Strauss. Published in 1967, the book is about how the theory discoveries of data obtained and analyzed from social research can be further advanced.

The prominent publication in the yellow cluster is the book called as Last Child in the Woods: Saving Our Children from Nature-Deficit Disorder (TCS=14, Connection=14) by Richard Louv. Published by Algonquin Books in 2005, the book focuses on the positive effects of their relationships with nature on the development of the children.

The co-citation network of the articles published on botanic gardens, national parks, and natural monuments in the Education/Educational Research category was examined. After the analysis, it was seen that a total of 1596 different authors were cited. Among these, 16 authors who received 5 or more citations were evaluated. The obtained results are given in Figure 8.

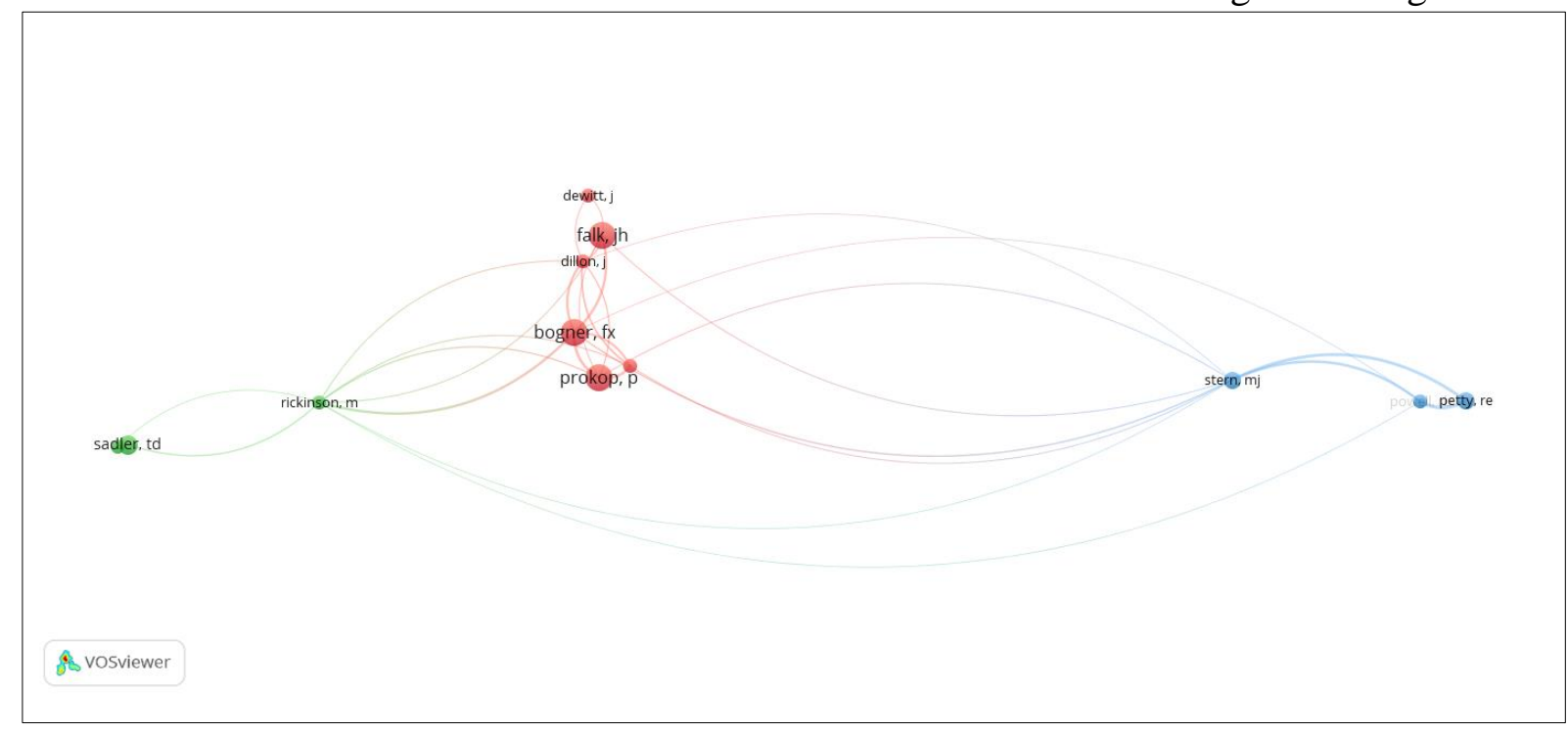

Figure 8. Author Co-Citation Network

When Figure 8 is examined, it is observed that the authors cited together in the articles published on botanic gardens, national parks, and natural monuments are grouped in 3 clusters. There are six authors in the red cluster, and three each in the green and blue clusters.

The leading author in the red cluster is Franz X. Bogner (TCS=55, Connection=7). The author continues his studies at the University of Bayreuth (Germany). The author mainly studies on environmental education.

The prominent author in the green cluster is Mark Rickinson (TCS=25, Connection=9). The author works at Monash University (Australia). The author, an education researcher, specializes in evidence-based practice and policy, and environmental and sustainability education.

The leading author in the blue cluster is Mark J. Stern (TCS=39, Connection=6). The author continues his studies at Virginia Tech University (USA). The study fields of author are human dimensions of natural resource policy and management, environmental communication, protected areas management, international conservation, natural resource management effectiveness, public response to natural resource management, and environmental education. 
The source co-citation network of the articles published on botanic gardens, national parks, and natural monuments in the Education/Educational Research category was examined. In the research, it was understood that a total of 1309 different sources were cited. Among these, 27 sources with 5 or more citations were evaluated. The obtained findings are provided in Figure 9.

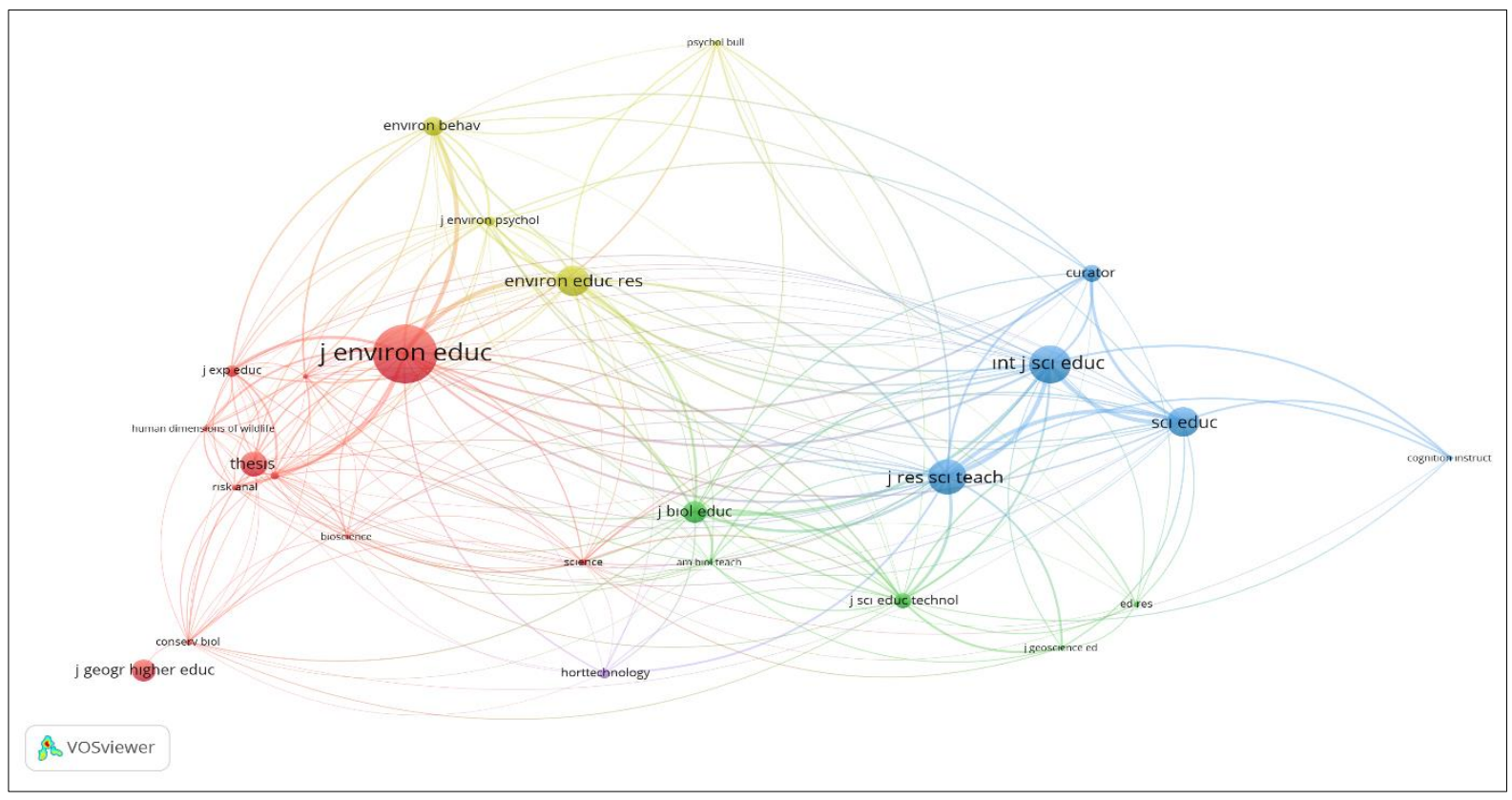

Figure 9. Source Co-Citation Network

When Figure 9 is examined, it is observed that the journals cited together in published articles on botanic gardens, national parks, and natural monuments are collected in 5 clusters. There are 11 sources in the red cluster, 5 sources in the green cluster, 5 sources in the blue cluster, 4 sources in the yellow cluster, and 1 source in the purple cluster.

The leading resource in the red cluster is The Journal of Environmental Education (TCS=700, Connection=22). The journal, which is under the roof of the Taylor \& Francis publishing house, has been operating since 1969 and publishes 6 issues a year. The journal, which is in the Q2 class, mainly includes studies in the field of environmental education and sustainability.

The prominent source in the green cluster is the Journal of Biological Education (TCS=322, Connection=19). The journal, which is under the roof of Taylor \& Francis publishing house, has been operating since 1967 and publishes 5 issues per year. The journal mainly publishes studies on biology education.

The leading source in the blue cluster is the Journal of Research in Science Teaching (JRST) (TCS=603, Connection=21). JRST, the official journal of NARST (A global organization for improving science education through research), has been operating since 1963 and publishes 10 issues per year. In the journal, where articles on different subjects are published, studies in the field of science education and teaching are intense.

The prominent resource in the yellow cluster is the journal Environmental Education Research $(\mathrm{TCS}=371$, Connection=20). The journal, which is under the roof of Taylor $\&$ Francis publishing house, has been operating since 1995 and publishes 12 issues a year. The 
articles published in the journal are generally about environmental education and environmental and sustainability education.

The only source in the purple cluster is HortTechnology $(\mathrm{TCS}=54$, Connection= 11). The journal, which is one of the publication organs of the American Society for Horticultural Science organization founded in 1903, has been continuing its activities since 1991 and publishes 6 issues a year. The journal mainly includes studies in the field of botanical science.

\section{Conclusion and Discussion}

Within the scope of the study, the distribution of the publications scanned with the keywords "botanic gardens", "national parks", and "natural monuments" by WoS categories was examined. As a result of the analysis, it is concluded that the highest number of records is in the Ecology category. Education/Educational Research category examined within the scope of this study ranks $66^{\text {th }}$ with 98 records. It is observed that scientific studies on botanic gardens, national parks, and natural monuments are mainly in such fields as ecology, zoology, biodiversity, environment and botanical sciences. However, it can be stated that the relationship between these subjects and the studies in the field of educational sciences is weak and that the studies are not at the desired level. Among the records in the category of Education/Educational Research, it is stated that the most publication type is articles and that the paper and the book chapter follow the article. When the bibliometric analysis studies conducted in different fields for the WoS database are examined in the literature, there are studies revealing that the most common type of publication is the article (Bozdoğan, 2020a; Bozdoğan, 2020c; Chao, Yang \& Jen 2007; Karagöz \& Şeref, 2019a; Sönmez, 2020; Yang, Sun \& Liu, 2017; Wang, Zhu, Song \& Hou, 2018).

When the distribution of the articles by the publication years is examined, it is comprehended that the first article was published in 1983 and continued at irregular intervals in the following period. In 2007 and the following years, it was determined that at least 1 article on the field of educational sciences was regularly published every year and that the maximum number of publications was reached with 8 articles in 2016. Considering that almost half of the articles have been published in the last 5 years, it can be mentioned that scientific studies on botanic gardens, national parks, and natural monuments in the field of education have accelerated in recent years. When the literature is examined, it is seen that similar results are obtained in studies conducted from out-of-school learning environments to science centers (Bozdoğan, 2020a), planetariums (Bozdoğan, 2020b), and museums (Bozdoğan, 2020c).

It is also seen that a total of 364 citations are made to the articles published in the field of education on botanic gardens, national parks, and natural monuments and that the most cited year is 2020. There is a cumulative increase in citations made especially after 2010. Considering that approximately two thirds of the citations have been made in the last 4 years, this increase in the number of citations can be attributed to the increase in the number of publications in recent years. Similar results are also obtained in some other studies on out-ofschool learning environments (Bozdoğan, 2020a; Bozdoğan, 2020b; Bozdoğan, 2020c). However, it is determined that there are a total of 9 articles that received 10 or more citations. It is concluded that almost two-thirds of the total citations are made to these 9 articles and that all of them are collective studies. Moreover, the most cited publication is the article titled as "What Difference Does It Make? Assessing Outcomes from Participation in a Residential Environmental Education Program” by Stern, Powell and Ardoin.

When the countries active within the scope of the articles published on botanic gardens, 
national parks, and natural monuments are examined, it is concluded that researchers from 21 different countries contribute to the field with their studies. In particular, it is seen that the USA is far ahead of other countries in terms of the number of articles. More than 1200 scientific studies conducted by researchers working in the USA on out-of-school learning environments also show its effectiveness in the environments that are the subject of this research. When the literature is examined, it is observed that there are studies that reach similar results (Bozdoğan, 2020a; Bozdoğan, 2020b; Bozdoğan, 2020c). Also, this situation can be associated with the fact that the USA is rich in environments such as botanic gardens, national parks, and natural monuments. Besides, the high number of articles by researchers working in Brazil can be associated with the geographical features of the country i.e., the Amazon rainforest, as well as with publications in the Brazilian-based REMEA journal, which publishes in Portuguese in the WoS database. It is observed that nearly half of the countries, including Turkey, contribute to the subject field with an article. Moreover, in the articles published on botanic gardens, national parks, and natural monuments, it is seen that researchers from 83 different institutions contributed to the field. Except for 6 institutions, it is determined that the others have 1 article on the subject field.

When the publication languages of the articles are examined, it is determined that the majority of them are in English. Similar results are obtained in the literature (Bozdoğan, 2020a; Bozdoğan, 2020c; Chao, Yang, \& Jen, 2007; Chiu \& Ho, 2007; Karagöz \& Şeref, 2019a; Sönmez, 2020). English is followed by Portuguese, Spanish, and Bulgarian. It is also found that the articles are published in 32 different journals. Considering that the languages of such journals as Environmental Education Research and Journal of Environmental Education, which publish the most in this field, are English, it is an expected result that the number of articles published in English is in majority.

When the keywords in the articles were examined in order to determine the current study topics in the articles published on botanic gardens, national parks, and natural monuments, it is determined that 180 different keywords are used and that the most used ones are environmental education and botanic garden. However, in recent years, it is observed that such keywords as citizen scientist, education for sustainable development, and sustainability have started to be used more frequently. From this point of view, it can be interpreted that the academic studies on the subject field in recent years have been designed within the framework of these subjects and concepts.

The most cited studies of 55 articles on the subject field are collected in 4 clusters. When the subjects in this cluster are examined, it is understood that the most cited studies are on the interest of the participants in environmental education programs, nature awareness, environmental management and learning, the negative effect of time spent in digital environments on visits to natural environments, and the effect of natural environments on the development of children. In general, it can be stated that the most citations are to the studies that deal with the relationship between natural environment and human.

When the articles about botanic gardens, national parks, and natural monuments are examined, it is determined that there are important researchers who direct this field. In this context, the studies conducted by Bogner, Prokop and Falk, especially for out-of-school learning environments, draw attention. Also, when the sources in which the studies cited in the 55 articles were published were examined, it is seen that the journals come to the forefront as the source type. It is determined that the most effective of these journals are The Journal of Environmental Education, Environmental Education Research, International Journal of 
Science Education, Journal of Biological Education (England), Journal of Research in Science Teaching, Science Education, Environment and Behavior (USA). It is observed that similar results are acquired in different studies on out-of-school learning environments (Bozdoğan, 2020a; Bozdoğan, 2020b). In line with the results, it can be interpreted that these journals focus on studies on out-of-school learning environments.

\section{Recommendations}

The articles in the WoS database were examined in the study, and this study can be carried out in different resource types (books, papers, and others.) in the same database. In addition, similar studies can be carried out in important databases (SCOPUS, ERIC, HW Wilson and so on) other than the WoS database. In this way, a wider range of educational research on botanic gardens, national parks, and natural monuments can be put forward. Moreover, postgraduate theses can be examined within the scope of the study to be conducted later. Citation analysis can also be applied in these theses.

\section{References}

Aksoy, B., Bozdoğan, K. \& Sönmez, Ö. F. (2021). An evaluation of the publications in the field of geography education: bibliometric analysis based on the Web of Science Database. Review of International Geographical Education (RIGEO), 11(2), 540-557. DOI: 10.33403rigeo.724741

Atmaca, S. (2012). Outdoor education activities in science education and effects of these activities on pre-service teachers. (Unpublished doctoral thesis). Hacettepe University Institute of Social Sciences, Ankara.

Ayaz, N. \& Türkmen, B. M. (2018). Bibliometric analysis of post-graduate theses on local foods. Gastroia: Journal of Gastronomy and Travel Research, 2(1), 22-38.

Bayındır, D. (2010). Reasons for student field trips to botanic gardens: A case from Turkey. (Unpublished master's thesis). Boğaziçi University Institute of Social Sciences, İstanbul.

Beşel F. \& Yardımcıŏlu, F. (2017). Bibliometric analysis of Maliye Dergisi (journal of finance): The period of 2007-2016. Maliye Dergisi, (172), 133-151.

Bostan Sarıoglan, A. \& Küçüközer, H. (2017). Investigation of preservice science teachers' opinions regarded to outdoor school learning environments. Journal of Research in Informal Environments, 2(1), 1-15.

Botanic Gardens Conservation International. (2021). About botanic gardens. https://www.bgci.org/about/about-botanic-garden/ taken from.

Bozdoğan, A. E. \& Ustaoğlu, F. (2016). Pre-service science teachers' views about instructional potential of planetariums. Journal of Turkish Science Education, 13(1), 38-49.

Bozdoğan, A. E. (2008). The assessment of the science centers of the pre-service science teachers in terms of science education: The case of Feza Gürsey Science Center. Journal of Uludag University Faculty of Education, 21(1), 19-41.

Bozdoğan, A. E. (2020a). A bibliometric analysis based on Web of Science Database: Articles published on science centres / museums related to educational researches. Mediterranean Journal of Educational Research, 14(31), 174-194. DOI: 10.29329/mjer.2020.234.9

Bozdoğan, A. E. (2020b). A bibliometric evaluation of published educational research papers on "planetariums" based on Web of Science Database. OPUS-International Journal of Society Researches, 16(27), 150-173. DOI: 10.26466/opus.672517 
Bozdoğan, K. (2020). A bibliometric analysis of educational studies about "museum education". Participatory Educational Research (PER), 7(3), 161-179. DOI: 10.17275/per.20.40.7.3

Bozok, D., Kılıç, S. N. \& Özdemir, S. S. (2017). Bibliometric analysis of rural tourism on tourism literature. Journal of Human Sciences, 14(1), 187-202.

Çetinkaya Bozkurt, Ö. \& Çetin, A. (2016). Bibliometric analysis of Journal of Entrepreneurship and Development. Journal of Entrepreneurship and Development, 11(2), 229-263.

Chao, J. J., Yang, J. M. \& Jen, W. Y. (2007). Determining technology trends and forecasts of RFID by a historical review and bibliometric analysis from 1991 to 2005. Technovation, 27(5), 268-279.

Chiu, W. T., \& Ho, Y. S. (2007). Bibliometric analysis of tsunami research. Scientometrics, 73(1), 3-17.

Çiçek, Ö. \& Saraç, E. (2017). Science teachers' opinions about experience in out of school learning environments. Ahi Evran University Journal of Kırşehir Education Faculty, 18(3), 504-522.

Coşkun Hepcan, Ç. \&Özkan, B. (2005). Determination of the facilities and services of botanic gardens as an urban open space. Journal of Agriculture Faculty of Ege University, 42(3), 159-170.

Demircan, N. \& Y1lmaz, H. (2004). A research on the formation of a botanical garden in Erzurum city. Atatürk University Journal of Agricultural Faculty, 35(3-4), 193-200.

Deniş, H. \& Genç, H. (2010). Investigating 8th class students' attitudes towards the national parks in their immediate environment ito the same variables (the case of Isparta province). The Journal of Graduate School of Natural and Applied Sciences of Mehmet Akif Ersoy University, 1(1), 9-25.

Deniş, H., Genç, H. \& Demirkaya, H. (2008). Development of an attitude scale to measure attitudes toward national park. Gazi University Journal of Gazi Educational Faculty, 28(2), 95-107.

Doğru, M., Güzeller, C., \& Çelik, M. (2019). A bibliometric analysis in the field of sustainable development and education from past to present. Adlyaman University Journal of Educational Sciences, 9(1), 42-68.

Dudley, N. (Ed.) (2008). Guidelines for applying protected area management categories. Gland, Switzerland: IUCN.

Ertaş, H., Şen, A. İ. \& Parmasizoğlu, A. (2011). The effects of out-of school scientific activities on 9th grade students' relating the unit of energy to daily life. Necatibey Faculty of Education Electronic Journal of Science and Mathematics Education, 5(2), 178-198.

Gerber, B.L., Cavallo, A.M.L., \& Marek, E.A. (2001). Relationships among informal learning environments, teaching procedures and scientific reasoning ability. International Journal of Science Education, 23(5), 535- 549.

Gökkaya, A. K. \& Yeşilbursa, C. C. (2009). The effect on academic success of using historical places in teaching social studies. The Journal of Turkish Educational Sciences, 7(2), 483-506.

Gülüm, K. \& Okuyucu, S. (2016). Using for educational purposes of Kazdağı National Park and its immediate environment's geopark potential. Route Educational and Social Science Journal, 3(4), 41-55.

Günay, B. (2019). The effects of inquiry approach of informal learning environment on academic achievements: Case of The Ege University Research and Application Center of Botanical Garden and Herbarium. (Unpublished master's thesis). Ege University Institute of Education Sciences, İzmir. 
Hannu, S. (1993). Science centre education: Motivation and learning in informal education. (Unpublished doctoral thesis). Helsinki University, Helsinki, Finland.

Howe, R. W. \& Disinger, J. F. (1988). Teaching environmental education using out of school settings and mass media. ERIC/SMEAC Environmental Education Digest, (1), 1-7.

İnceoğlu, Ç. (2014). A bibliometric analysis on the cinema studies doctoral theses in Turkey. Galatasaray University Journal of Communication, 21, 31-50.

İri Karadeniz, F. G. (2017). Reparing book about plants and the effects of the botanical garden trip on 6th grade students' plant awareness. (Unpublished master's thesis). Muğla Sitk1 Koçman University Institute of Education Sciences, Muğla.

Kalender, Ç. (2010). Evaluation of the nature educations in Turkey (Kaçkar Mountains National Park case study.) (Unpublished master's thesis). Artvin Çoruh University Graduate School of Natural and Applied Sciences, Artvin.

Karagöz, B. \& Koç Ardıç, İ. (2019). Bibliometric analysis of the articles published in Journal of Mother Tongue Education. Journal of Mother Tongue Education, 7(2), 419-435. 419.

Karagöz, B. \& Şeref, İ. (2019a). Literature review on reading in terms of bibliometric properties. Journal of Mother Tongue Education, 7(3), 781-799.

Karagöz, B. \& Şeref, İ. (2019b). Bibliometric analysis of researches on Yunus Emre. Mediterranean Journal of Educational Research, 13(27), 123-141. DOI: 10.29329/mjer.2019.185.6

Karagöz, B. \& Şeref, İ. (2020) A review of articles on the writing skill: Trends in the Web of Science Database. Journal of Mother Tongue Education, 8(1), 67-86.

Karakaş, A. \& Genç, H. (2020). An examination of teachers' attitudes towards the national park in their environment: The Isparta, Denizli example. Journal of Educational Issues, 6(2), 398-413.

Karaşah, B. \& Var, M. (2016). Determination of visitor preferences in botanic gardens 'case of Nezahat Gökyiğit Botanic Garden'. Kastamonu University Journal of Forestry Faculty, 16(1), 120-130.

Karsl1, G., Karamustafaoğlu, O. \& Kurt, M. (2019). The effect of botanical garden on socioscientific issues of students' perspectives in the teaching process: Sustainable environment. Journal of Computer and Education Research, 7(14), 437-463.

Kınasakal, İ., Demir, A. \& Kaymakc1, S. (2019). An example for using local history in the middle school 5th grade social studies course: Safranbolu trip. Turkish Studies Educational Sciences, 14(6), 3181-3202. DOI: 10.29228/TurkishStudies.36863

Kırboğa, O. (2020). Evaluation of the Munzur Valley National Park tourism potential in the scope of place based education. Eastern Geographical Review, 25(44), 201-216.

Kocalar, A. O. (2016). Students' opinions with regard to the role of national parks in the enhancement of ecological awareness. European Journal of Science and Technology, $5(9), 55-61$.

Koçman, A. (2004). Natural wonders of the "Burnt Land (Katakekaumene)": Volcanic features of Kula area. Aegean Geographical Journal, 13(1-2), 5-15.

Köksal, E. A. (2005, Eylül). Informal learning environments: Participants views of learning and teaching Environmental Education in National Parks. Presented at the Protected Natural Areas Symposium, Isparta.

Kurdoğlu, O., Kurdoğlu, B. Ç. \& Şen, G. (2005, Eylül). Role of protected areas in environmental education: Kaçkar Mountains National Park case study. Presented at the Protected Natural Areas Symposium, Isparta.

Laçin Şimşek, C. (2020). Natural monuments. C. Laçin Şimşek (Ed.). Out-of-school learning environments in science teaching in (233-246). Ankara: Pegem Academy Publishing. 
Li, K., Rollins, J. \& Yan, E. (2018) Web of Science use in published research and review papers 1997- 2017: A selective, dynamic, cross-domain, content-based analysis. Scientometrics, 115(1), 1-20.

Liu, X., Zhang, L. \& Hong, S. (2011). Global biodiversity research during 1900-2009: A bibliometric analysis. Biodiversity and Conservation, 20(4), 807-826.

Mertoğlu, H. (2019). Opinions of science pre-service teachers on out-of-school activities conducted in different learning environments. Journal of Research in Informal Environments (JRINEN), 4(1), 37-60.

Ocak, R. Ö. \& Öztürk Kurtaslan, B. (2015). Education function of botanical gardens. International Journal of Social, Behavioral, Educational, Economic, Business and Industrial Engineering, 9(6), 2184-2188.

Oğurlu, İ. (2010). Evaluation of effects on participants of a nature training projects. The Western Anatolia Journal of Educational Sciences (WAJES), 7(14), 59-101.

Öz, S., Bakır, S. \& Yıldırım, M. Z. (2013). Preservice science teachers' opinions about environmental education in national parks. Mehmet Akif Ersoy University Journal of The Institute of Educational Sciences, 2(3), 21-35.

Özay Köse, E. \& Gül, Ş. (2019). Investigation of high school students' attitudes about botanical gardens according to different variables. International Journal of Humanities and Education, 5(12), 1019-1036.

Özdemir, Ü. (1990). Natural monuments. The Journal of the Faculty of Languages and History-Geography, 34(1-2), 427-428.

Al, U. (2008). Scientific publication policy of Turkey: A bibliometric approach based on citation indexes. (Unpublished doctoral thesis). Hacettepe University Institute of Social Sciences, Ankara.

Becerikli, S. Y. (2013). A bibliometric analysis of master's and doctoral theses written on health communication: A critical review. Ankara Journal of Health Services, 12(2), 25-36.

Koley, S. \& Sen, B. K. (2016). Biobibliometric study of Professor A. S. Paintal: A celebrated medical physiologist. Library Herald, 54 (2), 174-190.

Özgen, N. (2011). A different approach to physical geography teaching method: Tripobservation supported education. Marmara Journal of Geography, 23, 373-388.

Papp, S. \&Thompson, G. (2015). What is a national park? Teachers guide. National Parks and Wildlife Service, Office of Environment and Heritage.

Parvathamma, N. \& Banu, N. (2013). Research contribution of Prof Atul H. Chokshi to materials science: A scientometric study. DESIDOC Journal of Library \& Information Technology, 33(5), 378-384.

Pritchard, A. (1969). Statistical bibliography or bibliometrics? Journal of Documentation, 25, 348-349.

Şahin, F. \& Sağlamer Yazgan, B. (2013). The effect of inquiry based outdoor laboratory activities on academic achievements of students. Sakarya University Journal of Education, 3(3), 107-122.

Şat, B. (2006). The functions of the arboreta on nature conservation and environmental education, and Ataturk Arboretum. Journal of the Faculty of Forestry Istanbul University, 56(2), 253-270.

Şeref, İ. \& Karagöz, B. (2019a). An evaluation of Turkish education academic field: bibliometric analysis based on Web of Science Database. Journal of Language Education and Research, 5(2), 213-231.

Şeref, İ. \& Karagöz, B. (2019b). Bibliometric evaluation based on Scopus Database: The studies carried out on Mevlana Jalaluddin Rumi. RumeliDE Journal of Language and Literature Studies, (14), 298-313. DOI: 10.29000/rumelide.541024 
Şimşek, A. \& Kaymakc1, S. (2015). Definition, purpose and scope of out-of-school social studies teaching. A. Şimşek ve S. Kaymakc1 (Ed.). Out-of-school social studies teaching in (s. 1-14) Ankara: Pegem Academy Publishing.

Sönmez, Ö. F. (2020). Bibliometric analysis of educational research articles published in the field of social study education based on Web of Science Database. Participatory Educational Research (PER), 7(2), 216-229. DOI: 10.17275/per.20.30.7.2

Swain, D. K. (2014). Journal bibliometric analysis: A case study on quality assurance in education. Indian Streams Research Journal, 4(4), 1-14.

Thompson, D. F. (2018). Bibliometric analysis of pharmacology publications in the United States: A state-level evaluation. Journal of Scientometric Research,7(3), 167-172.

Tsay, M. Y. \& Yang, Y. H. (2005). Bibliometric analysis of the literature of randomized controlled trials. Journal of the Medical Library Association, 93(4), 450-458.

Türkmen, H., Topkaç, D. D. \& Atasayar Yamık, G. (2016). The effect of field trips to informal learning environment on learning of "classification of living things": Case of the Natural History Museum and Botanical. Ege Journal of Education, 17(1), 174197.

Varışoğlu, B., Şahin, A., \& Göktaş, Y. (2013). Trends in Turkish education studies. Educational Sciences: Theory \& Practice, 13(3), 1767-1781.

Vekli, G. S. (2019). An activity based on inquiry driven science in nature: Biodiversity is under threat at national park!. Journal of Inquiry Based Activities, 9(2), 150-163.

Wang, P., Zhu, F., Song, H. \& Hou, J. (2018). A bibliometric retrospective of the journal Eurasia Journal of Mathematics, Science and Technology Education between 2012 and 2017. EURASIA Journal of Mathematics, Science and Technology Education, 14(3), 765-775. DOI: 10.12973/ejmste/80911

Wang, W. M. \& Ho, Y. S. (2017). Bibliometric analysis of art exhibit reviews in the Arts \& Humanities Citation Index. Malaysian Journal of Library \& Information Science, 22(1), 59-68.

Yalçın, H. \& Yayla, K. (2016). Main dynamics of folklore discipline: A scientometric analysis. National Folklore, (112), 42-60.

Yaltırık, F. (1969). Live and dried plant museums (arboretum, botanical garden, herbarium). Journal of the Faculty of Forestry Istanbul University, 19(1), 217-224.

Yang, L., Sun, T. \& Liu, Y. (2017). A bibliometric investigation of flipped classroom research during 2000-2015. International Journal of Emerging Technologies in Learning, 12(6), 178-186. DOI: 10.3991/ijet.v12i06.7095

Zaman, S. \& Coşkun, O. (2012). A suggestion for resource value usage of national parks: Nene Hatun Historical National Park. Atatürk University Journal of Graduate School of Social Sciences, 16(3), 117-134. 